\title{
p53 family proteins in thyroid cancer
}

\author{
$R$ Malaguarnera, $V$ Vella, $R$ Vigneri and F Frasca
}

Endocrinologia, Dipartimento di Medicina Interna e Medicina Specialistica, Università di Catania, PO Garibaldi Nesima, Via Palermo 636, 95122 Catania, Italy

(Requests for offprints should be addressed to R Vigneri; Email: vigneri@ unict.it)

\begin{abstract}
At variance with other human malignancies, p53 mutations are not frequent in thyroid cancer and are believed to be responsible mainly for cancer progression to poorly differentiated and aggressive phenotype. p63 and p73, two proteins with a high degree of homology with p53, are overexpressed in thyroid cancer, but their role in cancer initiation or progression is controversial. Regulation of p53 family protein function depends on: (1) the balance between the expression of transcriptionally active (p53, TAp63, and TAp73) and inactive isoforms ( $\Delta$ Np63 and $\Delta$ Np73); (2) their interaction and competition at DNA-responsive elements; (3) their interaction with regulatory proteins, either inhibitory or activating. In thyroid cancer, therefore, although mutations of the p53 oncosuppressor protein family are rare, other mechanisms are present, including aberrant expression of p53 family dominant negative isoforms, up-regulation of inhibitory proteins, and functional inhibition of activating proteins. The overall result is a defective oncosuppressor activity. These inactivating mechanisms may be present in the early stages of thyroid cancer and in different cancer histotypes. A better understanding of this complex network may not only ameliorate our comprehension of cancer biology, but also open the possibility of innovative diagnostic procedures and the development of targeted therapies.
\end{abstract}

Endocrine-Related Cancer (2007) 14 43-60

\section{p53 in thyroid cancer}

Oncogene gain of function is the most frequent molecular alteration described in thyroid cancer. It mainly includes the aberrant activation of the RAS/RAF/MEK/ERK pathway (Kroll 2004, Hunt 2005). These alterations regard the rearrangements of Ret/PTC and Trk tyrosine kinase receptors and point mutations of RAS or BRAF genes (Kroll 2004, Hunt 2005). Recently, mutations in the PI3KCA gene, resulting from the constitutive activation of the PI-3K pathway, have also been described in anaplastic thyroid carcinomas (Garcia-Rostan et al. 2005). Loss of function of tumor suppressor proteins may also occur in thyroid cancer and includes PAX-8/PPAR $\gamma$ rearrangement, PTEN down-regulation, $\beta$-catenin, and p53 mutations (Kroll 2004, Hunt 2005).

While inactivating mutations of the $p 53$ gene is very frequent in human cancers $(50 \%$ of all human malignancies), they have been found in only $10 \%$ of thyroid carcinomas (Olivier et al. 2002; Fig. 1A) and mainly in poorly differentiated and aggressive histotypes. These observations and the indolent progression of most thyroid carcinomas have brought to the paradigm that $\mathrm{p} 53$ role is minor in thyroid cancer initiation and early stages, while it is important only in the rare case of progression to aggressive phenotypes (Harvey et al. 1995). However, the role of p53 functional inactivation in thyroid cancer has never been carefully studied and remains controversial.

The p53 protein has three major functional domains, all conserved in the p53 homologs p63 and p73: the N-terminal transactivation domain (TAD), the C-terminal oligomerization domain (OD), and the core domain, which has DNA-binding activity (DNA-binding domain, DBD; Fig. 2A) (Murray-Zmijewski et al. 2006). The vast majority of p53 mutations occurs within the DBD domain (Olivier et al. 2002), thus impairing p53 binding to DNA (Fig. 1B). p53 is an important tumor suppressor, as it integrates multiple stress signals and regulates cell response to DNA damage by the induction of a series of target genes, which regulate cell cycle arrest. This allows DNA damage repair or apoptosis when cells are severely damaged (Murray-Zmijewski et al. 2006). These biological effects are elicited by p53 binding to responsive promoters which, in turn, activate the transcription of genes like $p 21$ (G1 cell growth arrest), 
A

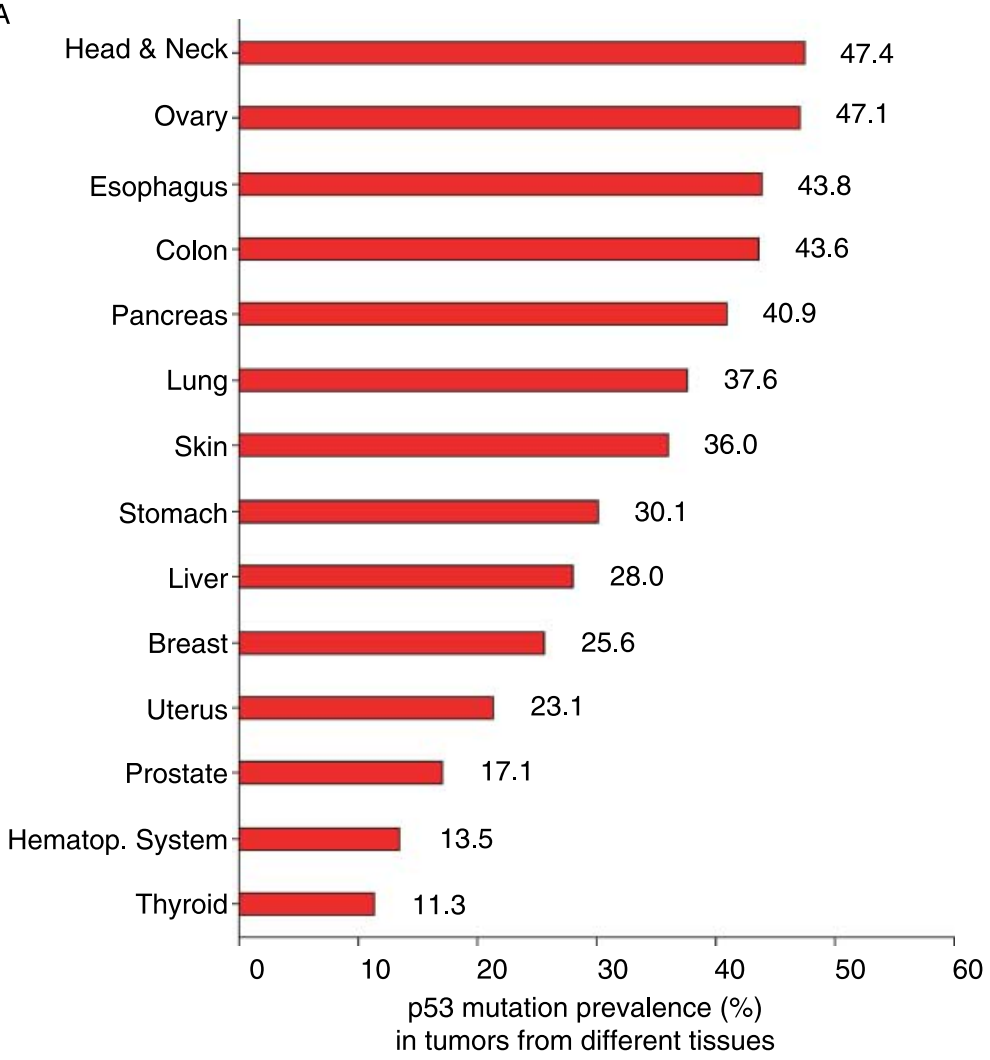

From IRAC TP53 Mutation Database, R10 release, July 2005 with modifications

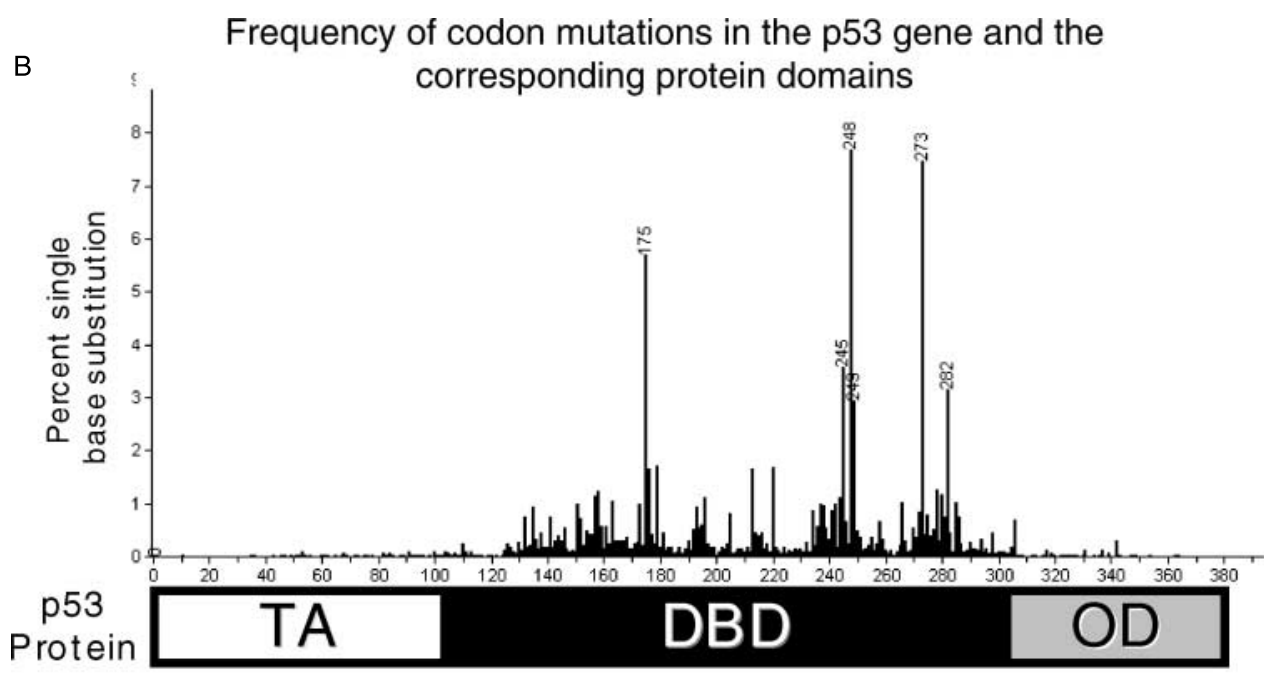

Codon number

From IRAC TP53 Mutation Database, R10 release, July 2005 with modifications

Figure 1 p53 inactivating mutations. (A) Frequency of p53 mutations among tumors from different human tissues. Mutations most frequently occur in the DNA-binding domain. (B) Frequency of mutations among the different codons of the p53 gene. Data are obtained from the indicated reference (Olivier et al. 2002). 

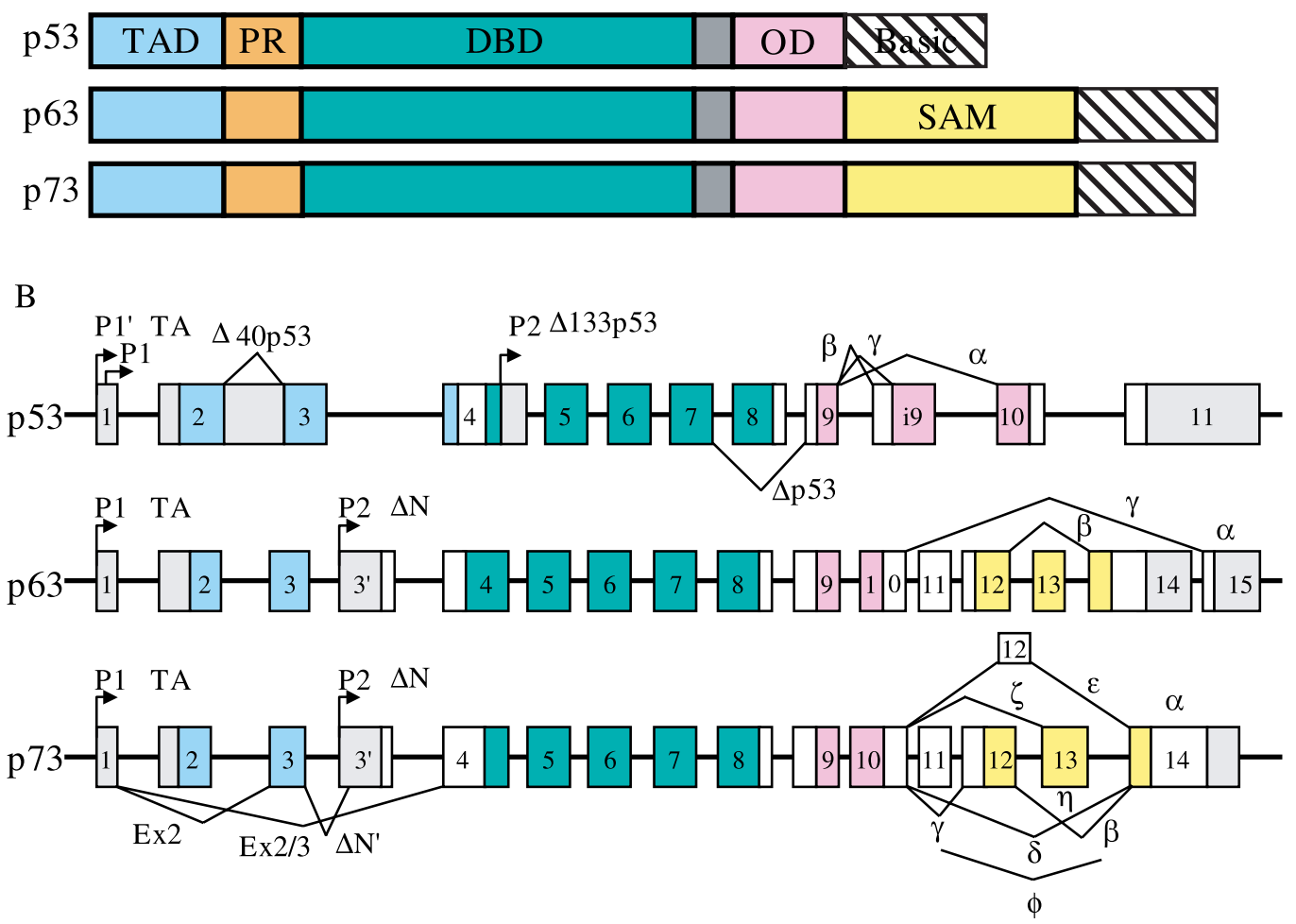

Figure 2 p53 family members and isoforms. (A) Functional domains of p53 family member genes. Blue, transactivation domain (TAD); orange, proline-rich region (PR); green, DNA-binding domain (DBD); pink, oligomerization domain (OD); yellow, sterile $\alpha$ motif (SAM); hatched, post-SAM basic domain. (B) Intron/exon structure. Introns are depicted in gray, while exons are colored according to the functional domains. All three genes express multiple splice variants and contain different internal promoters. The p53 isoforms include: TAp53, $\Delta 40$ p53 (generated by either alternative splicing of intron 2 or alternative initial translation site in exon 4 at codon 40 ), $\Delta \mathrm{p} 53$ (produced by alternative splicing of exons $7 / 9$ with a deletion of 66 amino acids within DBD), and $\Delta 133 p 53$ (generated using an internal promoter in intron 4). The alternative splicing of intron 9 gives rise to $\alpha, \beta$ and, $\gamma$ isoforms. Altogether, p53 gene can transcribe ten different variants: p53 $(\alpha, \beta, \gamma), \Delta 40$ p53 $(\alpha, \beta, \gamma), \Delta 133 p 53(\alpha, \beta, \gamma)$ and $\Delta$ p53 (Courtois et al. 2004 , Bourdon et al. 2005, Mills 2005, Rohaly et al. 2005, Mills 2006). In the case of p63 and p73, the proximal promoter P1 yields the TA isoforms, while the distal promoter $\mathrm{P} 2$, in intron 3 , gives rise to $\Delta \mathrm{Np} 63 / \mathrm{p} 73$-truncated variants. In addition, the $\mathrm{COOH}$-terminal splicing leads to $\mathrm{p} 73 \alpha, \beta, \gamma, \delta, \varepsilon, \zeta, \eta, \phi$ and $\mathrm{p} 63 \alpha, \beta, \gamma$ for both TA and $\Delta \mathrm{N}$ forms. Moreover, p73 can use an additional NH2-terminal splicing site, within exon 2, that produces $\Delta \mathrm{N}$ like proteins Ex2p73, Ex2/3p73, and $\Delta$ N'p73 (Moll \& Slade 2004).

Bax, and PUMA (apoptosis; Murray-Zmijewski et al. 2006). Another $p 53$ major target gene is $M d m 2$, encoding for an ubiquitin ligase that binds to the $\mathrm{N}$-terminus of the p53 protein and causes p53 inactivation, nuclear export, and degradation. Mdm2 induction in response to p53 is the major negative feedback loop aimed at restraining p53 proapoptotic function and thus allowing cell repair. p53 is also a major regulator of cell senescence. Indeed, telomere shortening caused by cell replications triggers p53 activation, thereby blocking cell cycle and favoring cell entry into senescence. As a consequence, p53 inactivation may contribute to the increased number of cell replications and, eventually, to the accumulation of further genetic abnormalities and the acquisition of the immortalized phenotype in cultured cells (Stewart \& Weinberg 2006). Finally, the $p 53$ gene can use different internal promoters and/or internal translation start sites to produce a variety of N-terminally truncated isoforms, with a variable degree of dominant negative activity. As depicted in Fig. 2B, the $p 53$ gene contains two upstream promoters ( $\mathrm{P} 1$ and $\mathrm{P} 1$ ') that transcribe $\Delta 40 \mathrm{p} 53$ and $\Delta \mathrm{p} 53$. Furthermore, the use of an internal promoter in intron 4 leads to an NH2-truncated p53 protein termed $\Delta 133 \mathrm{p} 53$ (Courtois et al. 2004, Bourdon et al. 2005, Mills 2005, Rohaly et al. 2005, Mills 2006).

While in anaplastic carcinomas (Salvatore et al. 1996, Quiros et al. 2005), mutations of both $R A S / B R A F$ and $p 53$ genes may be observed, in well-differentiated thyroid cancer, $B R A F$ and $R A S$ mutations, but not $p 53$ mutations, are frequent. This suggests the possibility that p53 mutations may occur as a secondary event, concomitant with the loss of cell differentiation. 
Factors favoring $p 53$ mutations in thyroid cancer are not fully understood. In vitro experiments have shown that exposure of immortalized human thyroid cells to either $\alpha$-particles or $\gamma$-rays causes p53 mutations and the acquisition of cell ability to be tumorigenic in nude mice (Gamble et al. 1999). In vivo, however, the relationship between exposure to radiation and p53 mutation is less clear. Studies performed in the Belarus population after the Chernobyl accident did not prove a definitive correlation between radiation exposure and p53 mutations in thyroid cancer (Nikiforov et al. 1996, Smida et al. 1997, Suchy et al. 1998, Pisarchik et al. 2000). Recent evidences suggest that p53 mutations in thyroid cancer may be favored by the genomic instability occurring during the tumor progression process (Shahedian et al. 2001).

Other studies on p53 protein expression in a large series of thyroid tumor specimens suggest that, although not mutated, p53 activity may be inhibited in thyroid cancer by other mechanisms. Indeed, increased p53 protein levels were observed by immunohistochemistry not only in anaplastic and poorly differentiated thyroid cancer, where p53 mutations are frequent, but also in well-differentiated cancers, in the absence of any p53 mutation (Soares et al. 1994, Pollina et al. 1996, Park et al. 1998). Nonfunctioning p53 cannot induce Mdm2, its major degrading protein, and consequently accumulates in the cell nucleus. A strong p53 staining in paraffinembedded specimens, therefore, is considered indirect evidence of nonfunctioning p53. Nuclear accumulation of wild-type p53 protein and reduced p53 tumor suppressor function in some differentiated thyroid cancers is also suggested by the observation of a correlation between elevated p53 protein content and poor clinical outcome (Dobashi et al. 1993, Gerasimov et al. 1995, Nishida et al. 1996, Ruter et al. 1996, Hosal et al. 1997, Godballe et al. 1998, Chen et al. 1999). Wild-type p53 inactivation is also suggested by in vitro studies in thyroid cancer cells: H-RAS-transformed rat thyrocytes display wild-type $\mathrm{p} 53$ protein accumulation (Burns et al. 1992) and isolated rat thyroid cancer cells in culture display both wild-type p53 overexpression and a defect in G1 arrest in response to DNA damage (Wyllie et al. 1995). Several independent mechanisms may be hypothesized to explain the wild-type p53 inactivation in thyroid carcinomas, including p53 cytoplasmic retention (Zedenius et al. 1996) and Mdm2 overexpression (Jennings et al. 1995, Zou et al. 1995). Indeed, in a large series of differentiated thyroid cancer specimens, immunohistochemistry indicated that $\mathrm{Mdm} 2$ is overexpressed and its expression level directly correlates with a poor clinical outcome (Jennings et al. 1995, Zou et al. 1995, Czyz et al. 2001, Horie et al. 2001).

In addition to its role in tumor progression in poorly differentiated thyroid cancer, p53 inactivation has also been implicated in chemoresistance (Blagosklonny et al. 1998, Ceraline et al. 2003, Hassan et al. 2006). Several reports indicate that wild-type p53 gene delivery into anaplastic thyroid cancer cells induces a partial differentiation, with the re-expression of thyroid specific-genes, and makes cells more vulnerable to the effect of chemotherapy (Fagin et al. 1996, Moretti et al. 1997, Blagosklonny et al. 1998). This effect may be increased by the concomitant use of histone deacetylase inhibitors, which stimulate p53 acetylation and functional activation (Imanishi et al. 2002). More recently, in anaplastic thyroid cancer, p53 mutations were used as a target for oncolytic viruses. For instance, the $E 1 B$ gene-defective adenovirus (ONYX-15), which is able to replicate only in cells that are p53 defective, was used to kill anaplastic thyroid cancer cells both in vitro and in vivo (Portella et al. 2003, 2002). These approaches of gene therapy, although novel and intriguing, are unlikely to be available for clinical use in the next future because of some concerns about cell-killing efficiency.

In conclusion, although p53 is rarely mutated in thyroid cancer and mainly in undifferentiated tumors, the paradigm that it is only involved in advanced cancer progression is today contradicted by a series of evidences indicating that it may also play a role in the early stages of thyroid cancer. In these tumors, wild-type p53 activity may be inhibited by several inactivating mechanisms acting on the protein and/or its signaling pathway.

\section{Other members in p53 family: p63 and p73}

Two novel genes, named $p 63$ and $p 73$, have recently been discovered as members of the p53 tumor suppressor family because of their remarkable similarity with p53 structure and functional domains (Lohrum \& Vousden 2000). Structural homology between these three proteins suggests that they also share similar tumor suppressor functions. However, recent studies have demonstrated that the functions of these proteins are not entirely redundant since each of them can behave as a p53 agonist or antagonist, and can also play its own unique biological tasks (Courtois et al. 2004, Moll \& Slade 2004).

Like p53, p63 and p73 also contain three major domains: the TAD, the DBD, and the (OD) (Moll et al. 2001). Similarly, p63 and p73 also are expressed as multiple isoforms, the products of alternative splicing, and the use of two different promoters. P1 promoter, 
upstream of exon 1, yields full-length proteins (TAp63 and TAp73, containing the TA domain), while P2, spanning intron 3 , produces $\mathrm{NH} 2$-terminally truncated forms $\Delta \mathrm{Np} 63$ and $\Delta \mathrm{Np} 73$ (missing TAD). The latter isoforms may play a dominant negative function (Moll \& Slade 2004) by both competition for DNA binding and oligomerization with isoforms containing the TA domain. Moreover, p73 can undergo alternative splicing of exon 2, producing additional isoforms lacking the TAD (Ex2p73, Ex2/3p73, and $\Delta N^{\prime}$ p73).

Additional complexity to this network of protein isoforms arises from multiple splicing of the $\mathrm{COOH}$ terminus, skipping one or several exons (Moll \& Slade 2004). Thus far, several COOH-terminus transcripts have been identified for p53 family members: $\alpha, \beta, \gamma$ for p53 (Fig. 2B); $\alpha, \beta, \gamma$ for p63; and $\alpha, \beta, \gamma, \delta, \varepsilon, \zeta, \eta$, $\phi$ for p73. Interestingly, the $\alpha$ isoforms of p73 and p63 (but not of p53) contain a sterile $\alpha$ motif (SAM; Fig. 2A) that mediates specific protein-protein interactions (Ghioni et al. 2002, Blandino \& Dobbelstein 2004). With respect to p63 and p73 activity, it depends on many factors, including their expression pattern and the functional crosstalk between full-length protein and other isoforms.

Several reports have indicated that, whereas p53 protein is ubiquitously expressed, p63 and p73 expression is more restricted and dependent on cell differentiation and development stage (Blandino \& Dobbelstein 2004). For instance, p63 is expressed in proliferating basal cells of the epidermis and squamous epithelia (Mills et al. 1999) and p63-deficient mice exhibit defects in the epithelia as well as craniofacial malformations. In humans, p63 germ-line missense mutations cause Ectrodactyly, Ectodermal displasia, facial Clefts (EEC) and Ankyloblepharon, Ectodermal displasia, Clefting (AEC) syndromes (Celli et al. 1999, Mills et al. 1999, Fomenkov et al. 2003).

Like p63, p73 also has its own distinct development functions (Yang et al. 2000). p73 knockout mice show site-specific development defects in hippocampus, immune system, and behavior (Yang et al. 2000, Benard et al. 2003). Moreover, $\Delta \mathrm{Np} 73$ has been shown to inhibit neuronal apoptosis by blocking p53 proapoptotic function (Pozniak et al. 2000, Casciano et al. 2002). These observations suggest that $\mathrm{p} 73$ and $\Delta \mathrm{Np} 73$ play an important role in development and differentiation, by protecting neuronal precursors from apoptotic death (Pozniak et al. 2000).

Different isoforms of p53 family members can play opposite roles, depending on various conditions. Ectopic TAp63 and TAp73 are able to bind to p53responsive promoters and cause p53-like functions (tumor suppressor) in human cells, whereas the
$\mathrm{N}$-terminally truncated $\Delta \mathrm{Np} 63$ and $\Delta \mathrm{Np} 73$ isoforms may have an oncogenic role by antagonizing fulllength TAp63, TAp73, and TAp53 (Benard et al. 2003). Thus, the tumor suppressor function of these proteins depends on the balance between the different isoforms expressed in different cells and tissues.

Recent findings suggest that TAp63 and TAp73, isoforms that have potential tumor suppressor activity, under certain conditions may also be involved in the acquisition and maintenance of the transformed phenotype.

TAp63 and TAp73 are very rarely mutated in cancer cells and often overexpressed. These observations are in concert with a possible role of these proteins in tumorigenesis (Ikawa et al. 1999, Yang et al. 2000, Moll 2003, Flores et al. 2005). Interestingly, in some tumors, this overexpression is concomitant with that of the dominant negative isoforms $\Delta \mathrm{Np} 63$ and $\Delta \mathrm{Np} 73$, which may override the effects of the transcriptionally active isoforms explaining why, as a final effect, p63 and p73 may function as oncogenes (Moll 2003). A possible role of p63 and p73 in cancer progression might also be explained by the ability of each protein isoform to affect the functions of the other members of the family (Lohrum \& Vousden 2000). For instance, p53 mutants can oligomerize with p63 and p73 transcriptionally active isoforms via the DBD and inhibit their transcriptional activity. On the other hand, p63 and p73 can antagonize wild-type p53 binding to the DNA-responsive promoters (Strano et al. 2001). In this way, p63 and p73 isoforms may differentially interfere with the biological properties of wild-type p53, inhibiting its tumor suppressor activity and thereby conferring a selective survival advantage to cancer cells (Benard et al. 2003). These observations provide a possible explanation for the negative role of p63 and p73 overexpression in many human cancers, (Hibi et al. 2000, Benard et al. 2003, Mills 2006).

In conclusion, the discovery of p53 homologs, p63 and $\mathrm{p} 73$, has clarified that p53 exerts its tumor suppressor function in association with its homologs, within a complex network of physical and functional interactions, where the specific activities of TAp63 and TAp73 are still less understood than those of p53, because their expression level and the function of different isoforms and their regulation have not yet been studied. Undoubtedly, understanding the relationship between these three proteins and their isoforms with either overlapping or opposite roles will provide intriguing insights into new and exciting therapeutic approaches for cancer. 


\section{p63 and thyroid cancer}

A possible role of $\mathrm{p} 63$ in the malignant transformation of thyroid follicular cells is supported by two lines of evidence: (1) p63 is involved in epithelial cell differentiation (Yang et al. 1998, Reis-Filho et al. 2003, Reis-Filho \& Schmitt 2002); and (2) a number of human epithelial malignancies express a high levels of p63 isoforms (Hibi et al. 2000, Marin \& Kaelin 2000, Moll et al. 2001, Massion et al. 2003, Moll \& Slade 2004). How p63 isoform expression pattern may influence tumor progression, however, remains unclear.

A specific role of p63 in thyroid cancer was first denied by studies performed in paraffin-embedded specimens, which did not detect p63 in either normal or malignant thyroid tissues (Di Como et al. 2002). Subsequent studies, however, found p63 immunostaining in a small subset of papillary and anaplastic thyroid carcinomas (Preto et al. 2002, Reis-Filho et al. 2003, Reis-Filho \& Schmitt 2002), but not in normal thyroid tissue, nodular goiter, and oncocytic follicular adenomas (Unger et al. 2003, Burstein et al. 2004).

The latter results were confirmed by the immunohistochemistry experiments performed in frozen thyroid tissues, where the TAp63 $\alpha$ protein was found in a high percentage of thyroid carcinomas, but, again, not in normal thyroid cells and benign adenomas (Malaguarnera et al. 2005.). In the same study, RT-PCR, western blot and immunohistochemistry indicated that TAp63 $\alpha$ is the predominant isoform expressed in both thyroid cancer tissues and malignant thyroid cells in permanent culture (Malaguarnera et al. 2005). One possible explanation for the discrepancy between these studies and the previous ones is that the paraffin-embedding process could damage the p63 epitopes, thereby preventing its detection by immunohistochemistry (Malaguarnera et al. 2005).

Although the high prevalence of TAp63 $\alpha$ expression in thyroid cancer suggests its possible role in thyroid carcinogenesis, no clue is available on the specific function of TAp63 $\alpha$ in thyroid cancer initiation and/or progression. TAp63 $\alpha$, in fact, may display bifunctional properties (either tumorigenic or tumor suppressor) depending on the cellular context (Mills 2006), its binding to different target gene promoters, and the interaction with specific proteins. When functional studies on p63 were performed in order to evaluate $p 63$ effects on target genes, at variance with other human cell types where p63 exerts some p53-like functions (Zhu et al. 1998, Sasaki et al. 2001), in thyroid cancer cell lines, no effect was observed in terms of transactivation of $\mathrm{p} 53$-responsive promoters p21, bax, and Mdm2 (Malaguarnera et al. 2005). In thyroid cancer cells, therefore, the tumor suppressor activity of endogenous TAp63 $\alpha$ is absent. Moreover, ectopic TAp63 $\alpha$ also failed to induce $p 21$, bax , and $M d m 2$ genes, thereby suggesting the existence of an inhibiting mechanism, not due to the TAp63 $\alpha$ molecule but due intrinsically to thyroid cancer cells (Malaguarnera et al. 2005).

A defect downstream of TAp63 $\alpha$ was ruled out because the ectopic expression of p53 (which activates similar signaling pathways) was still able to transactivate target genes and to exert tumor suppressor activity in these cells (Malaguarnera et al. 2005). Since the inhibition of target gene expression was restricted to p63, a specific p63 inhibitor, i.e. $\Delta \mathrm{Np} 63 \alpha$, which is often up-regulated in cancers (Yang et al. 1998, Crook et al. 2000, Hibi et al. 2000, Park et al. 2000, Yamaguchi et al. 2000, Massion et al. 2003) was evaluated, but was not detected in thyroid cancer tissues and cell lines by RT-PCR (Malaguarnera et al. 2005).

Finally, co-immunoprecipitation experiments excluded that the inhibitory mechanism was the direct interaction between the core domains of TAp $63 \alpha$ and p53 mutants (Gaiddon et al. 2001, Strano et al. 2001), with the formation of complexes that impair TAp63 $\alpha$ transcriptional activity (Malaguarnera et al. 2005), a mechanism that is anyway unlikely in well-differentiated thyroid carcinomas, which seldom harbor p53 mutations.

Interestingly, thyroid cancer cell transfection with p63 isoforms different from TAp63 $\alpha$ (i.e. TAp63 $\beta$ and TAp63 $\gamma$ ) was able to elicit the activation of $p 63$ target genes (Malaguarnera et al. 2005). Recently, a C-terminal inhibitory domain was identified in TAp63 $\alpha$, but not in TAp63 $\beta$ and TAp63 $\gamma$ isoforms. This domain is both necessary and sufficient for TAp63 $\alpha$ transcriptional activity inhibition, since it binds to the TAD and masks the residues that are important for the protein transactivation activity (Moll et al. 2001, Serber et al. 2002). The TAp63 $\alpha$ C-terminal domain also includes a SAM domain, which is a protein-protein interaction sequence (Thanos \& Bowie 1999, Ghioni et al. 2002). It is possible to speculate, therefore, that one or more co-repressor protein(s) are present in thyroid cancer cells and may interact with this domain, present in the TAp63 $\alpha$ isoform but not in TAp63 $\beta$ and TAp63 $\gamma$ isoforms, and, consequently, specifically inhibit only TAp63 $\alpha$ transcriptional activity (Malaguarnera et al. 2005). This possibility is under investigation in our laboratory.

As an additional mechanism for TAp63 $\alpha$ tumorigenic activity in thyroid cancer, we have to consider that TAp63 $\alpha$, devoid of oncosuppressor activity, may bind DNA at the same sites than p53 (Yang et al. 1998) and, therefore, antagonize p53 oncosuppressor activity 
by competition, preventing the binding of more transcriptionally active p53 family members (Malaguarnera et al. 2005). Indeed, in thyroid cancer cells, TAp63 $\alpha$ prevents the effect of p53 on thyroid cancer cell viability and foci formation at an extent comparable with that of $\Delta \mathrm{Np} 63 \alpha$ (Fig. 3). This antagonistic role of TAp63 $\alpha$ against p53 in thyroid cancer is confirmed by gene silencing experiments: suppression of p63 expression by siRNA causes an improvement of p53 transcriptional function and oncosuppressor activity (Malaguarnera et al. 2005).

These data indicate that TAp63 $\alpha$ has an oncogenic rather than oncosuppressor role in thyroid cancer by a variety of mechanisms, including counteraction of p53 tumor suppressor function. Recent evidence, indicating that in mice TAp63 overexpression is able to accelerate skin tumorigenesis by up-regulating pro-tumorigenic proteins, confirms the potential tumorigenic role of TAp63 $\alpha$ (Koster et al. 2006).

The mechanisms underlying this aberrant p63 expression in malignant thyroid cells are not clear. One possible explanation is that p63 expression is a direct consequence of cancer cell origin. A subset of papillary thyroid carcinomas may originate from pluripotent, p63-positive embryonic remnants, more biologically labile than mature thyrocytes and thereby more susceptible to undergo oncogenic changes leading to papillary thyroid carcinomas (Burstein et al. 2004). In concert with this possibility is the observation of a similar p63 immunostaining in solid cell nests of the normal thyroid (remnants of the ultimo-brachial body) and in some papillary thyroid cancers (Reis-Filho et al. 2003, Burstein et al. 2004).

Since in thyroid cancer cells alterations of p53 signaling and abnormal p63 expression may be present at the same time, it is not possible to attribute to p63 expression a causative role in thyroid tumor development (Hibi et al. 2000, Di Como et al. 2002, Westfall
\& Pietenpol 2004). On the other hand, there is no evidence that the pro-oncogenic role of p63 can be attributed only to p53 tumor suppressor activity inhibition. As already mentioned, the possibility that p63 may confer oncogenic properties to pluripotent stem cells cannot be excluded.

In conclusion, we know that p63 may have an oncogenic rather than oncosuppressor function in thyroid cancer, but mechanisms and specific role in the p53 family protein network require a better understanding.

\section{p73 and thyroid cancer}

Although a large amount of data is available on p73 expression in human malignancies, data on human thyroid cancer are scanty. A quantitative RT-PCR analysis indicates that both TAp73 and $\Delta \mathrm{Np} 73$ transcripts are present in a consistent number of human thyroid carcinomas, although no correlation was found with the tumor clinical and pathological characteristics (Ferru et al. 2006). At immunohistochemistry, the presence of $\mathrm{p} 73$ and $\Delta \mathrm{Np} 73$ staining was observed in human thyroid cancer specimens, predominantly at nuclear level (Frasca et al. 2003, Ito et al. 2006), and RT-PCR analysis confirmed that both TAp $73 \alpha$ and $\Delta \mathrm{Np} 73 \alpha$ are expressed in malignant, but not in normal, thyroid tissues.

Data in tissues were confirmed by in vitro studies: RT-PCR and Western blot detected TAp73 $\alpha$ and $\Delta \mathrm{Np} 73 \alpha$ isoforms in the large majority of thyroid cancer cell lines from different histotypes (papillary, follicular, and anaplastic), but not in normal cultured thyrocytes. These data suggest that $\mathrm{p} 73$ expression in cancer cells is related to thyroid malignant transformation (Frasca et al. 2003, Vella et al. 2003, Ito et al. 2006). Similarly to TAp63 $\alpha$, the presence of TAp $73 \alpha$, a protein with potential tumor suppressor activity, is also counter-intuitive in malignant thyroid cells.

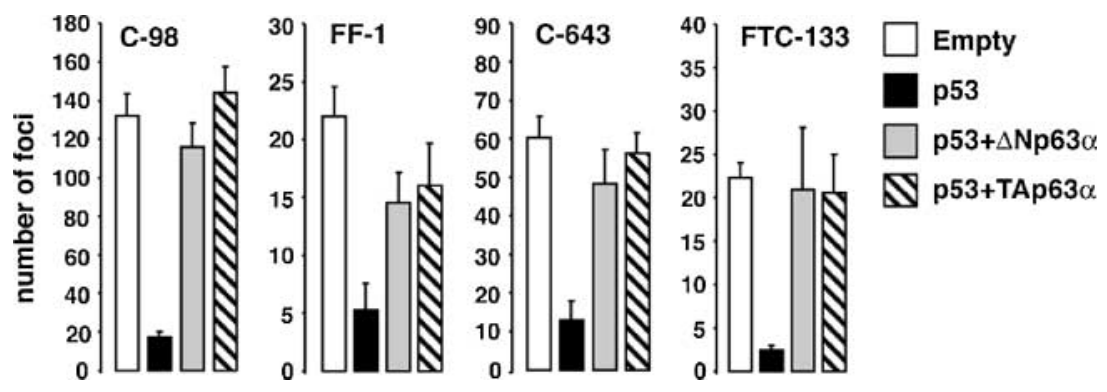

Figure 3 In thyroid cancer cells, TAp63 $\alpha$ prevents p53 tumor suppressor function. The indicated thyroid cancer cell lines were transfected with either empty vector (white bars), p53 (black bars), p53 plus $\Delta$ Np63 $\alpha$ (gray bars), or p53 plus TAp63 $\alpha$ (hatched bars). Transfected cells were then subjected to antibiotic selection with G418. Compared with empty vector, p53 dramatically inhibited the number of foci formation, whereas co-transfection with the dominant negative p63 isoform $\Delta$ Np63 $\alpha$ prevented the p53 suppression on colony formation, as expected. Surprisingly, also TAp63 $\alpha$ co-transfection inhibited p53-driven foci suppression. 
To clarify this issue, functional studies were carried out and indicated that, in thyroid cancer cells, TAp $73 \alpha$ is not functional in response to the DNA-damaging agent doxorubicin and fails to cause G1 arrest and/or apoptosis (Frasca et al. 2003, Vella et al. 2003).

TAp73 mutations, which rarely occur in human tumors (including central nervous system, lung, and breast; Melino et al. 2002), were never found in thyroid cancer cells by $\mathrm{p} 73$ mRNA sequence analysis. Moreover, ectopic TAp73 $\alpha$ activity was also blunted in thyroid cancer cells, suggesting that inactivating mechanisms other than mutations are present (Melino et al. 2002).

Previous studies had shown that the apoptotic function of $\mathrm{p} 73$ is regulated by the c-Abl tyrosine kinase (Agami et al. 1999, Gong et al. 1999). Differences in c-Abl expression and activity were not found in either normal or malignant thyroid cells (Vella et al. 2003). In the latter, however, indirect immunofluorescence staining and nuclear/cytoplasmic fraction separation revealed a predominant cytoplasmic localization of c-Abl and a reduced nuclear import, suggesting that the subcellular segregation of c-Abl and $\mathrm{p} 73$ could contribute to the defective activation of p73 tumor suppressor function. To explore this hypothesis, we used an Abl construct with constitutive nuclear localization (AblNuk; Fig. 4) and bound to a FK506-binding protein (FKBP) sequence, to allow dimerization and conditioned activation (McWhirter et al. 1993, McWhirter \& Wang 1997, Klemm et al. 1998, Yang et al. 1998, Smith \& Van Etten 2001). When the nuclear AblNuk-FKBP was activated by the presence of the dimerizer AP20187 (Fig. 4), apoptosis occurred in p73-positive, but not in p73-negative thyroid cancer cells (Fig. 4), indicating that when c-Abl can reach $\mathrm{p} 73$ in the nucleus, the oncosuppressor function will follow. Co-expression of either p73DD (which interferes with $\mathrm{p} 73$ oligomerization) or the baculovirus $\mathrm{p} 35$ protein, a potent inhibitor of caspases (Clem 2001), reduced the apoptotic response. These results indicate that in thyroid cancer cells, the restoration of c-Abl nuclear import can induce a p73and caspase-dependent apoptosis (Fig. 4).

Thyroid cancer cell lines used in these studies are derived from poorly differentiated cancer and harbor p53 mutations (Frasca et al. 2003). Previous reports demonstrated that p53 mutants may interact with TAp73 and inhibit its function (Gaiddon et al. 2001, Frasca et al. 2003). Indeed, co-immunoprecipitation experiments performed in these thyroid cancer cells showed that, at variance with TAp63 $\alpha$, TAp73 $\alpha$ interacts with p53 mutants. This is an additional p73 inactivating mechanism, which may occur in poorly differentiated thyroid cells where p53 is frequently mutated. In
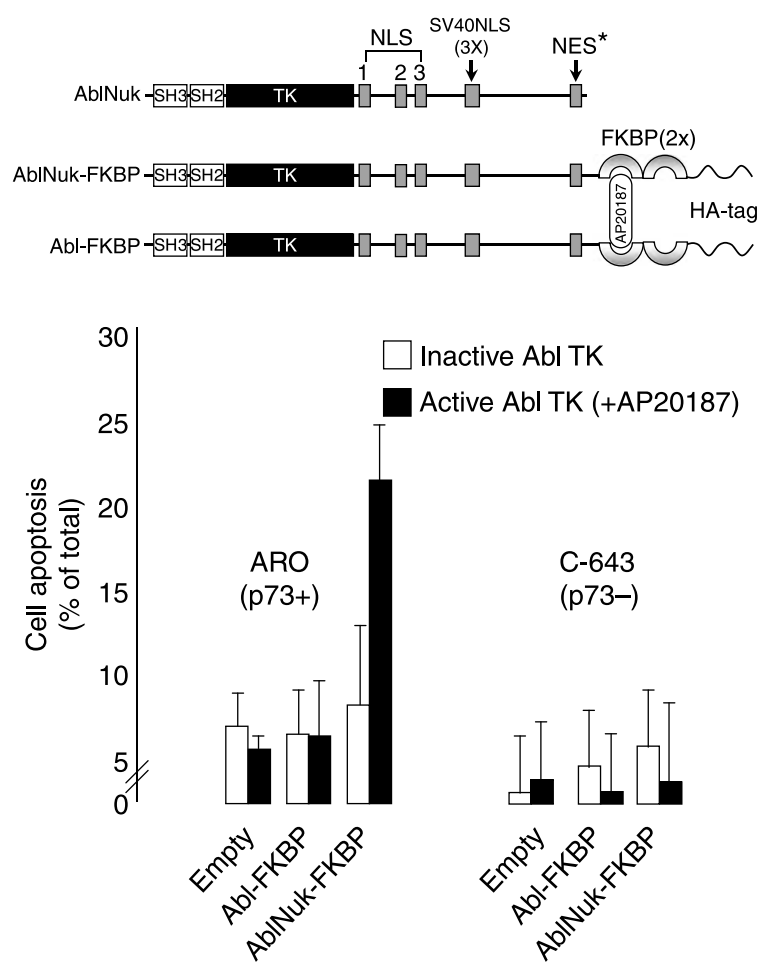

Figure 4 Restoration of c-Abl nuclear import activates p73 tumor suppressor function. Diagram of AbINuk, AbINuk-FKBP, and Abl-FKBP. To render Abl constitutively nuclear, its nuclear export sequence was inactivated with a single point mutation $\left(\mathrm{NES}^{\star}\right)$, whereas three copies of SV40 nuclear localization signals (SV4ONLS(3X)) were inserted in-frame downstream of the native NLSs of c-Abl (AbINuk). To conditionally activate c-Abl tyrosine kinase through dimerization, two copies of FKBP were fused to the $C$ terminus of c-Abl and AP20187 was employed as a dimerizer (Abl-FKBP). ARO (p73-positive) and C-643 (p73negative) thyroid cancer cells were transfected with either AbINuk-FKBP or Abl-FKBP and treated (black bars), with $50 \mathrm{nM}$ AP20187 (dimerizer) to activate Abl tyrosine kinase (Abl TK). Restoration of c-Abl nuclear import by AbINuk-FKBP transfection induced apoptosis in p73-positive thyroid cancer cells (ARO, left), but not in p73-negative cancer cells (C-643, right).

addition, previous studies suggested that in ovarian cancer and leukemia cells, TAp73 $\alpha$ antagonizes p53 transcriptional activity (Vikhanskaya et al. 2000, 2001, Freebern et al. 2003): this is another possibility that cannot be excluded in thyroid cancer cells. Finally, co-immunoprecipitation experiments indicated that TAp73 $\alpha$ may also interact with its dominant negative isoform $\Delta \mathrm{Np} 73 \alpha$, which, at variance with $\Delta \mathrm{Np} 63 \alpha$, is highly expressed in thyroid cancer cells.

Overall, these data indicate that the presence of either p53 mutants or $\Delta \mathrm{Np} 73 \alpha$ contributes to the functional inactivation of TAp $73 \alpha$ in thyroid cancer cell lines. In many human tumors including thyroid cancer, in fact, TAp73 $\alpha$ is co-expressed with the dominant negative isoform $\Delta \mathrm{Np} 73 \alpha$ (Frasca et al. 2003), as a consequence of the fact that $\operatorname{TAp} 73 \alpha$ is a 
major inducer of $\Delta \mathrm{Np} 73 \alpha$ (Nakagawa et al. 2003). In some thyroid cancer, $\Delta \mathrm{Np} 73 \alpha$ is expressed at a higher level than TAp73 $\alpha$ (resulting in an increased $\Delta$ N/TAp73 expression ratio), a condition that in other tumors (i.e. ovarian cancer) is related to an increased aggressiveness and chemoresistance (Casciano et al. 2002, Zaika et al. 2002, Concin et al. 2004, 2005, Ugur et al. 2004, Guan \& Chen 2005, Muller et al. 2005, Dominguez et al. 2006). $\Delta \mathrm{Np} 73 \alpha$ is also expressed in well-differentiated thyroid cancers that have a wildtype p53. In these well-differentiated tumors, $\Delta \mathrm{Np} 73 \alpha$ expression may represent an additional mechanism for inactivating the tumor suppressor function of $\mathrm{p} 53$. In these cases, TAp $73 \alpha$ expression may be considered indirectly responsible for wild-type p53 inactivation via the induction of $\Delta \mathrm{Np} 73 \alpha$ expression (Fagin et al. 1993, Frasca et al. 2003).

In summary, (a) p73 expression is a marker of thyroid cell malignant transformation, (b) overall, the biological role of TAp73 $\alpha$ in malignant thyroid cells may be ambivalent and depends on many different factors, and (c) the interactions of the various p73 isoforms within the molecular network of p53 family members are complex and await additional investigation.

\section{All p53 family members are inhibited by HMGA1 up-regulation in thyroid cancer cells}

The high mobility group A factors (HMGA1a, HMGA1b, and HMGA2) are non-histone proteins, with several different functions, including gene transcription, malignant transformation promotion, and metastatic progression (Reeves 2001, Sgarra et al. 2004). All members of the HMGA family contain multiple copies of a DNA-binding site called the 'AT-hook', which binds to the narrow minor groove of stretches of AT-rich DNA sequences. In addition, the HMGA proteins participate in specific protein-DNA and protein-protein interactions that induce both structural changes in chromatin and formation of stereospecific complexes called 'enhanceosomes' on the promoter/enhancer regions of genes. The expression level of $H M G A$ genes is maximal during the embryonic development, while it is very low in well-differentiated and adult cells (Zhou et al. 1995, Chiappetta et al. 1996, Hirning-Folz et al. 1998). HMGA proteins are rapidly induced by growth factor stimulation and are involved in the control of cell proliferation (Ayoubi et al. 1999). Consistent with such a growth regulatory role, homozygous mutations in the Hmga2 gene in mice result in the pygmy or 'minimouse' phenotype (Zhou et al. 1995).
Increased expression of HMGA proteins may promote a transformed phenotype in cell lines (Reeves 2001, Wood et al. 2000a, 2000b, Treff et al. 2004a, 2004b) and transgenic mice overexpressing HMGA proteins develop tumors (Fedele et al. 2002, 2005, Xu et al. 2004). In thyroid cancer, as in several human cancers (including colorectal, prostate, breast, cervical, lung), the HMGA1 protein level is high and correlates with the increasing degree of malignancy and metastatic potential (Sgarra et al. 2004). Interestingly, the use of HMGA2 antisense vector results in the suppression of both HMGA1 and HMGA2 synthesis and in the prevention of the retrovirus-mediated neoplastic transformation of rat thyroid cells (Berlingieri et al. 1995). The requirement for HMGA1 expression during rat thyroid cell transformation is further confirmed by antisense techniques specific for HMGA1 (Berlingieri et al. 2002). Moreover, suppression of HMGA1 protein synthesis by adenoviruses causes apoptosis in anaplastic human thyroid cancer cell lines leading to a drastic decrease in tumor growth in vivo (Scala et al. 2000). Despite these numerous lines of evidence regarding the pro-tumorigenic role of HMGA, the mechanism(s) underlying this effect are still poorly understood.

In thyroid cancer cells, all the three p53 family members are present with an expression pattern that is complex and different in different tumors (Ruter et al. 1996, Frasca et al. 2003, Vella et al. 2003, Malaguarnera et al. 2005). In general, the tumor suppressor activity of these proteins is kept latent by several mechanisms, including interaction with p53 mutants, dominant negative isoform overexpression, and impaired activation mechanisms. Since HMGA overexpression is very common in thyroid cancer, the possibility of an interference of HMGA proteins on p53 family oncosuppressor function was investigated. In several thyroid cancer cells of different histotypes, HMGAl gene silencing indicated that HMGA1 protein has an inhibitory effect on both ectopic and endogenous p53 family member activity (Fig. 5A). Moreover, fluorescence activated cell sorting (FACS) analysis indicated that HMGA1 is able to inhibit p53 activity on G1 cell cycle arrest and apoptosis, both under basal conditions and after exposure to the DNAdamaging agent doxorubicin (Fig. 5B). Co-immunoprecipitation experiments showed that HMGA1 protein directly interacts with all members of the p53 family. Further experiments with deletion mutants demonstrated that the C-terminal oligomerization domain of the p53 family members is required for the direct interaction with the HMGA1 protein (Frasca et al. 


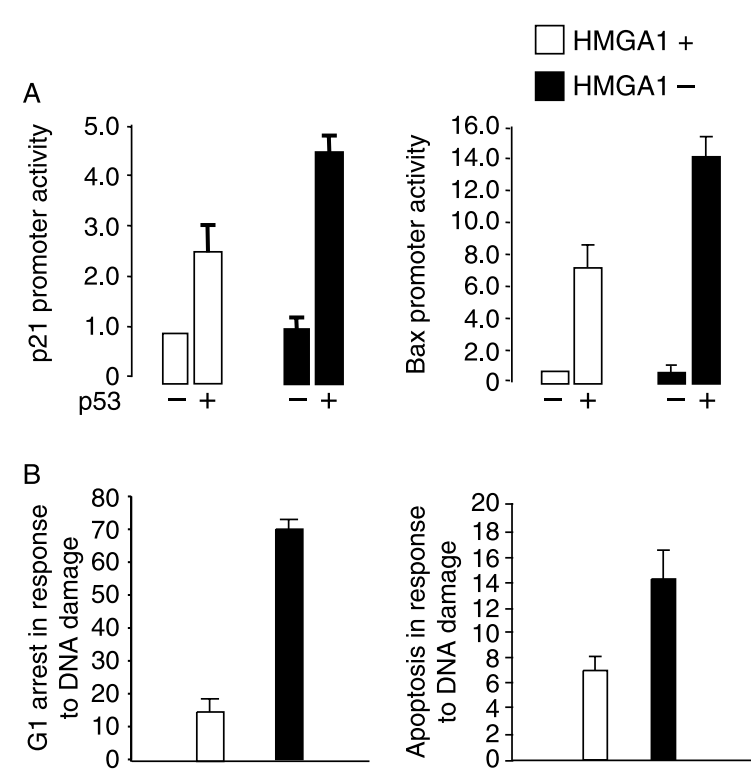

Figure 5 HMGA1 inhibits the function of p53, TAp63 $\alpha$, and TAp73 $\alpha$ in thyroid cancer cells. TPC- 1 thyroid cancer cells were silenced for HMGA1 by siRNA. In these cells, ectopic p53 transcriptional activity was increased by HMGA1 depletion (compare black with white bars in A). Depletion of HMGA1 resulted in increased p53-mediated G1 arrest and apoptosis in response to DNA damage (compare black with white bars in $\mathrm{B}$ ).

2006). Indeed, HMGA1 silencing resulted in increased p53 oligomerization in response to doxorubicin in thyroid cancer cells. Moreover, electrophoretic mobility shift assays indicated that the interaction of HMGA1 with p53 attenuates p53 DNA-binding activity (Frasca et al. 2006).

These data indicate that HMGA1 overexpression is another mechanism by which p53 family member function is kept latent in thyroid cancer cells and that HMGA1 directly interacts with the oligomerization domain of p53 family transcription factors, thereby preventing proper oligomerization, DNA binding, and, as a consequence, transcriptional and tumor suppressor activity (Frasca et al. 2006). Since HMGA1 overexpression is very common in thyroid cancer and occurs also in well-differentiated histotypes, it is reasonable to suppose that the p53-blunted function due to overexpressed HMGA1 is also a very common mechanism and may explain the positive correlation between HMGA1 expression and poor prognosis in some thyroid carcinomas. These observations also suggest that p53 network inactivation may be an important prerequisite for oncogene-driven thyroid cancer progression.

The specific mechanism, leading to HMGA1 up-regulation during thyroid malignant transformation, remains to be elucidated.

\section{Clinical applications of p53 family member expression in thyroid cancer}

\section{Possible role of p53 family proteins as diagnostic markers}

Since p53 family protein expression is mostly restricted to thyroid malignant tissue, it may represent a hallmark of thyroid cell malignant transformation (Dobashi et al. 1993, Nishida et al. 1996, Ruter et al. 1996, Zedenius et al. 1996, Preto et al. 2002, Frasca et al. 2003, Unger et al. 2003, Vella et al. 2003, Hunt et al. 2004, Malaguarnera et al. 2005).

In the last 10 years, several attempts have been made to identify by immunohistochemistry protein markers (single or in combination) that are able to differentiate benign from malignant thyroid nodules. These marker proteins have included Galectin-3 (Orlandi et al. 1998), CD44v6 (Bartolazzi et al. 2001), HBME-1 (Miettinen \& Karkkainen 1996), CK19 (Schelfhout et al. 1989), hTERT (Wood et al. 2000a), and S100A4 (Ito et al. 2004). The recent availability of microarray techniques has allowed a different approach, through the identification of clusters of genes, whose expression is specific of some types of thyroid tumors and malignancies (Lubitz et al. 2005, Musholt et al. 2006). Since a consistent series of thyroid malignant tissues display a positive immunostaining for at least one of the p53 family members (Table 1; Frasca et al. 2003, Malaguarnera et al. 2005, unpublished results), it is reasonable to hypothesize a possible use of these proteins in thyroid nodule differential diagnosis by immunostaining in both tissue specimens and cytoaspirates. Commercially available anti-p53 family protein antibodies have not yet been extensively tested and their possible use for this purpose requires further investigations.

\section{Possible role of p53 family proteins in thyroid cancer chemoresistance}

In several cancer types, chemoresistance has been attributed to the presence of p53 mutants (Koike et al. 2004). Thyroid carcinomas are very resistant to chemotherapy agents, including doxorubicin and cisplatin (Asakawa et al. 1997), even when p53 mutations are not present in these tumors. One possible explanation is that 553 family members with dominant negative function, that are often expressed in thyroid cancer, may inhibit p53 activity and account for chemoresistance (Frasca et al. 2003, Vella et al. 2003, Malaguarnera et al. 2005). Indeed, in other tumors (i.e. ovary cancer), TAp73 $\alpha$ is believed to be responsible for chemoresistance by antagonizing p53 activities (Vikhanskaya et al. 2001), a similar effect has 
Table 1 Immunostaining of p53 family members in frozen human thyroid samples

\begin{tabular}{|c|c|c|c|c|}
\hline & p53 & p63 & $\Delta \mathrm{Np73}$ & p73 \\
\hline \multicolumn{5}{|c|}{ Normal $(n=8)$} \\
\hline $74 \mathrm{~N}$ & - & - & - & - \\
\hline $81 \mathrm{~N}$ & - & - & - & - \\
\hline $89 \mathrm{~N}$ & - & - & - & - \\
\hline $143 N$ & - & - & - & - \\
\hline $212 \mathrm{~N}$ & - & - & - & - \\
\hline $390 \mathrm{~N}$ & - & - & - & - \\
\hline $560 \mathrm{~N}$ & - & - & - & - \\
\hline $361 \mathrm{~N}$ & - & - & - & - \\
\hline \multicolumn{5}{|c|}{ Adenomas $(n=7)$} \\
\hline $196 \mathrm{~A}$ & ++ & + & - & - \\
\hline $206 \mathrm{~A}$ & - & - & - & + \\
\hline $212 \mathrm{~A}$ & - & - & - & - \\
\hline $218 \mathrm{~A}$ & - & - & - & ++ \\
\hline $232 \mathrm{~A}$ & - & - & - & - \\
\hline $387 \mathrm{~A}$ & - & - & - & - \\
\hline $392 \mathrm{~A}$ & - & - & - & +++ \\
\hline \multicolumn{5}{|c|}{ Papillary $(n=9)$} \\
\hline $201 \mathrm{P}$ & ++ & + & NE & NE \\
\hline $321 \mathrm{P}$ & ++ & +++ & +++ & +++ \\
\hline $340 \mathrm{P}$ & + & + & +++ & ++++ \\
\hline $354 \mathrm{P}$ & +++ & ++ & ++ & ++ \\
\hline $360 \mathrm{P}$ & ++ & ++ & +++ & ++ \\
\hline $380 \mathrm{P}$ & ++ & ++ & ++ & ++ \\
\hline $383 P$ & + & ++ & NE & $\mathrm{NE}$ \\
\hline $386 \mathrm{P}$ & ++ & ++ & ++ & + \\
\hline $395 \mathrm{P}$ & +++ & ++ & +++ & ++ \\
\hline \multicolumn{5}{|c|}{ Follicular $(n=7)$} \\
\hline $97 \mathrm{P}$ & ++ & ++ & ++++ & ++ \\
\hline $146 P$ & + & + & NE & NE \\
\hline $191 \mathrm{P}$ & ++ & +++ & ++ & + \\
\hline $260 P$ & + & + & NE & NE \\
\hline $267 P$ & ++ & +++ & +++ & +++ \\
\hline $283 P$ & ++ & +++ & +++ & +++ \\
\hline $371 \mathrm{P}$ & +++ & ++ & +++ & +++ \\
\hline \multicolumn{5}{|c|}{ Anaplastic $(n=11)$} \\
\hline $6 \mathrm{P}$ & ++ & - & ++++ & ++++ \\
\hline $17 \mathrm{P}$ & + & + & ++ & + \\
\hline $32 \mathrm{P}$ & +++ & ++ & NE & NE \\
\hline $96 \mathrm{P}$ & ++++ & ++ & +++ & ++ \\
\hline $103 P$ & ++ & ++ & +++ & +++ \\
\hline $161 \mathrm{P}$ & +++ & +++ & +++ & +++ \\
\hline $164 \mathrm{P}$ & ++++ & +++ & $\mathrm{NE}$ & $\mathrm{NE}$ \\
\hline $219 P$ & +++ & +++ & +++ & + \\
\hline $238 \mathrm{P}$ & ++++ & +++ & +++ & +++ \\
\hline $241 \mathrm{P}$ & ++++ & - & ++++ & ++ \\
\hline $333 \mathrm{P}$ & +++ & +++ & +++ & +++ \\
\hline
\end{tabular}

- , No expression; + , low expression, ++ , moderate expression: +++ , high expression; ++++ , very high expression; NE, not evaluated.

been reported for $\Delta \mathrm{Np} 73 \alpha$ in several cancer types (Concin et al. 2005). At this regard, we have observed that cells transfected with an ecydisone-inducible $\Delta \mathrm{Np} 73 \alpha$ are more resistant to doxorubicin-induced apoptosis (unpublished results). In the light of these results, studies on the relationship between the expression pattern of p53 family members in thyroid cancer cells and tumor chemoresistance should be carried out for future clinical application.

\section{Possible role of p53 family proteins in gene therapy}

The high frequency of p53 mutations in the anaplastic histotype of thyroid cancer encouraged several attempts to restore wild-type p53 status by gene delivery, in order to make these cells more differentiated and sensitive to chemotherapy (Moretti et al. 1997, Blagosklonny et al. 1998, Narimatsu et al. 1998, Nagayama et al. 2000, Imanishi et al. 2002). Results obtained with ectopic expression of wild-type p53, however, have been disappointing. In the light of complexity of the p53 family protein network, the failure of ectopic p53 overexpression to cure thyroid cancer can be explained by many reasons. The ectopic wild-type p53 activity may be neutralized by a variety of mechanisms, including the interference of TAp63 $\alpha$, $\Delta \mathrm{Np} 73 \alpha$, and HMGA1 proteins. Moreover, the dominant negative function of p53 mutants expressed in poorly differentiated thyroid cancers and the reduced ectopic wild-type p53 stability, due to the robust Mdm2 induction occurring in infected/transfected cells, may be additional mechanisms of failure of p53 activation (Zeimet \& Marth 2003). According to this view it is possible that, to be effective, p53 gene delivery should be accompanied, for instance, by antisense sequences aimed at down-regulating TAp63 $\alpha, \Delta$ Np73 $\alpha$, and HMGA1 in thyroid cancer cells. An alternative approach could be the delivery of a mixture of $\mathrm{p} 53$ family members aimed at neutralizing the effect of dominant negative isoforms present in malignant cells. To this end, p53 gene delivery could be accompanied by TAp63 $\gamma$ gene delivery. TAp63 $\gamma$, in fact, is devoid of SAM domain and is able to neutralize the TAp63 $\alpha$ dominant negative effect on p53 by direct oligomerization (Malaguarnera et al. 2005). In a similar manner, the addition of TAp $73 \alpha$ to $p 53$ gene delivery may neutralize $\Delta \mathrm{Np} 73 \alpha$ by oligomerization and also increase p53 stability by competing with p53 for Mdm2 binding (Save et al. 1998, Balint et al. 1999). Finally, the use of a c-Abl analog with constitutive nuclear localization may restore TAp73 function and its tumor suppressor activity (Fig. 6).

Recently, pharmacogenomic approaches have also been proposed, with the use of synthetic compounds able to bind specifically to the DBD of the p53 mutants and to restore their proper protein configuration, and, thus, allow DNA binding (Bykov et al. 2002, Tanner \& Barberis 2004). These small synthetic compounds 


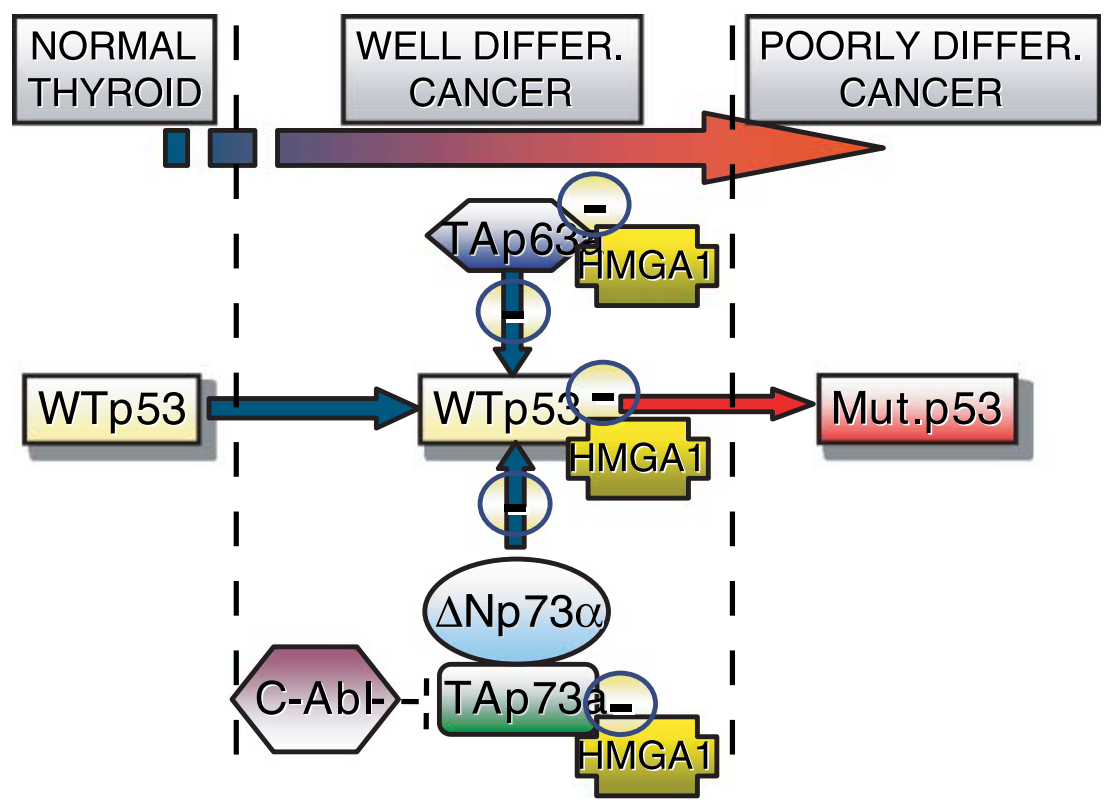

Figure 6 Schematic representation of a possible network among p53 family members in thyroid cancer cells. Normal thyrocytes express a functional wild-type p53, which may exert a tumor suppressor activity in response to DNA damage (left). Well-differentiated thyroid carcinomas express not only wild-type p53, but also other p53 family members with a dominant negative function (middle). As a result of different mechanisms, the oncosuppressor activity may be blunted: (1) TAp63 $\alpha$, which may be regarded as a de-differentiation marker, may antagonize p53 transcriptional activity by occupying p53-responsive promoters; (2) TAp73 $\alpha$ tumor suppressor activity may be kept latent by c-Abl nuclear exclusion; (3) $\Delta \mathrm{Np} 73 \alpha$, on the one side, may inactivate TAp73 $\alpha$ by both oligomerization and promoter occupancy and, on the other side, may antagonize p53 by promoter occupancy. In addition, HMGA1 overexpression may inhibit all transcriptionally active p53 family members ( $p 53$, TAp63 $\alpha$, and TAp73 $\alpha$ ) by interfering with protein oligomerization. In undifferentiated and anaplastic thyroid cancer, p53 may be inactivated by point mutations (right). p53 mutants not only have lost their tumor suppressor function, but may also inhibit TAp73 $\alpha$ by direct interaction via the core domain.

could be used in combination with traditional chemotherapy to sensitize poorly differentiated thyroid cancer cells to the cytotoxic effect of these agents.

\section{Conclusions}

Although p53 mutations are rare in thyroid cancers, p53 functional inactivation by a variety of different mechanisms is apparently very common. The involved mechanisms are based on the very complex network of p53 family member isoforms and include the expression of proteins with dominant negative function (i.e. $\Delta \mathrm{Np} 73 \alpha$ and TAp63 $\alpha$ ). Malfunction or overexpression of regulatory proteins is other, independent, inhibitory mechanisms. p53 inactivation by these mechanisms may be an important prerequisite for oncogene-driven thyroid cell transformation (in the early stages of cancer) and in cancer progression and may render thyroid cancer cells resistant to the common chemo- and gene therapy approaches. The unraveling of such a complex network may result helpful not only for better understanding of the important aspects of thyroid tumor progression, but also to design novel multi- targeted therapies for the poorly differentiated and most aggressive thyroid carcinomas.

\section{Acknowledgements}

This work was partially supported by grants and fellowships from Associazione Italiana per la Ricerca sul Cancro (AIRC), MIUR-PRIN 2004 and American Italian Cancer Foundation (AICF).

\section{References}

Agami R, Blandino G, Oren M \& Shaul Y 1999 c-Abl and p73 interact and collaborate to induce apoptosis. Nature 399 809-813.

Asakawa H, Kobayashi T, Komoike Y, Maruyama H, Nakano Y, Tamaki Y, Matsuzawa Y \& Monden M 1997 Chemosensitivity of anaplastic thyroid carcinoma and poorly differentiated thyroid carcinoma. Anticancer Research 17 2757-2762.

Ayoubi TA, Jansen E, Meulemans SM \& Van de Ven WJ 1999 Regulation of HMGIC expression: an architectural transcription factor involved in growth control and development. Oncogene 18 5076-5087. 
Balint E, Bates S \& Vousden KH 1999 Mdm2 binds p73 a without targeting degradation. Oncogene 18 3923-3929.

Bartolazzi A, Gasbarri A, Papotti M, Bussolati G, Lucante T, Khan A, Inohara H, Marandino F, Orlandi F, Nardi F et al. 2001 Application of an immunodiagnostic method for improving preoperative diagnosis of nodular thyroid lesions. Lancet 357 1644-1650.

Benard J, Douc-Rasy S \& Ahomadegbe JC 2003 TP53 family members and human cancers. Human Mutation 21 182-191.

Berlingieri MT, Manfioletti G, Santoro M, Bandiera A, Visconti R, Giancotti V \& Fusco A 1995 Inhibition of HMGI-C protein synthesis suppresses retrovirally induced neoplastic transformation of rat thyroid cells. Molecular and Cellular Biology 15 1545-1553.

Berlingieri MT, Pierantoni GM, Giancotti V, Santoro M \& Fusco A 2002 Thyroid cell transformation requires the expression of the HMGA1 proteins. Oncogene 21 2971-2980.

Blagosklonny MV, Giannakakou P, Wojtowicz M, Romanova LY, Ain KB, Bates SE \& Fojo T 1998 Effects of p53expressing adenovirus on the chemosensitivity and differentiation of anaplastic thyroid cancer cells. Journal of Clinical Endocrinology and Metabolism 83 2516-2522.

Blandino G \& Dobbelstein M 2004 p73 and p63: why do we still need them? Cell Cycle 3 886-894.

Bourdon JC, Fernandes K, Murray-Zmijewski F, Liu G, Diot A, Xirodimas DP, Saville MK \& Lane DP 2005 p53 isoforms can regulate p53 transcriptional activity. Genes \& Development 19 2122-2137.

Burns JS, Blaydes JP, Wright PA, Lemoine L, Bond JA, Williams ED \& Wynford-Thomas D 1992 Stepwise transformation of primary thyroid epithelial cells by a mutant Ha-ras oncogene: an in vitro model of tumor progression. Molecular Carcinogenesis 6 129-139.

Burstein DE, Nagi C, Wang BY \& Unger P 2004 Immunohistochemical detection of p53 homolog p63 in solid cell nests, papillary thyroid carcinoma, and hashimoto's thyroiditis: a stem cell hypothesis of papillary carcinoma oncogenesis. Human Pathology 35 465-473.

Bykov VJ, Issaeva N, Shilov A, Hultcrantz M, Pugacheva E, Chumakov P, Bergman J, Wiman KG \& Selivanova G 2002 Restoration of the tumor suppressor function to mutant p53 by a low-molecular-weight compound. Nature Medicine 8 282-288.

Casciano I, Mazzocco K, Boni L, Pagnan G, Banelli B, Allemanni G, Ponzoni M, Tonini GP \& Romani M 2002 Expression of DeltaNp73 is a molecular marker for adverse outcome in neuroblastoma patients. Cell Death and Differentiation 9 246-251.

Celli J, Duijf P, Hamel BC, Bamshad M, Kramer B, Smits AP, Newbury-Ecob R, Hennekam RC, Van Buggenhout G, van Haeringen A et al. 1999 Heterozygous germline mutions in the p53 homolog p63 are the cause of EEE syndrome. Cell 99 143-153.

Ceraline J, Deplanque G, Noel F, Natarajan-Ame S, Bergerat JP \& Klein-Soyer C 2003 Sensitivity to cisplatin treatment of human K1 thyroid carcinoma cell lines with altered p53 function. Cancer Chemotherapy and Pharmacology 51 91-95.

Chen BK, Ohtsuki Y, Furihata M, Takeuchi T, Iwata J, Liang SB \& Sonobe H 1999 Co-overexpression of p53 protein and epidermal growth factor receptor in human papillary thyroid carcinomas correlated with lymph node metastasis, tumor size and clinicopathologic stage. International Journal of Oncology 15 893-898.

Chiappetta G, Avantaggiato V, Visconti R, Fedele M, Battista S, Trapasso F, Merciai BM, Fidanza V, Giancotti V, Santoro M et al. 1996 High level expression of the HMGA1 gene during embryonic development. Oncogene 13 2439-2446.

Clem RJ 2001 Baculoviruses and apoptosis: the good, the bad, and the ugly. Cell Death and Differentiation 8 137-143.

Concin N, Becker K, Slade N, Erster S, Mueller-Holzner E, Ulmer H, Daxenbichler G, Zeimet A, Zeillinger R, Marth C et al. 2004 Transdominant DeltaTAp73 isoforms are frequently up-regulated in ovarian cancer. Evidence for their role as epigenetic p53 inhibitors in vivo. Cancer Research 64 2449-2460.

Concin N, Hofstetter G, Berger A, Gehmacher A, Reimer D, Watrowski R, Tong D, Schuster E, Hefler L, Heim K et al. 2005 Clinical relevance of dominant-negative p73 isoforms for responsiveness to chemotherapy and survival in ovarian cancer: evidence for a crucial p53p73 cross-talk in vivo. Clinical Cancer Research 11 8372-8383.

Courtois S, de Fromentel CC \& Hainaut P 2004 p53 protein variants: structural and functional similarities with p63 and p73 isoforms. Oncogene 23 631-638.

Crook T, Nicholls JM, Brooks L, O'Nions J \& Allday MJ 2000 High level expression of deltaN-p63: a mechanism for the inactivation of p53 in undifferentiated nasopharyngeal carcinoma (NPC)? Oncogene 19 3439-3444.

Czyz W, Kuzdak K, Pasieka Z, Timler D \& Brzezinski J 2001 p53, MDM2, bcl-2 staining in follicular neoplasms of the thyroid gland. Folia Histochemica et Cytobiologica 39 167-168.

Di Como CJ, Urist MJ, Babayan I, Drobnjak M, Hedvat CV, Teruya-Feldstein J, Pohar K, Hoos A \& CordonCardo C 2002 p63 Expression profiles in human normal and tumor tissues. Clinical Cancer Research 8 494-501.

Dobashi Y, Sakamoto A, Sugimura H, Mernyei M, Mori M, Oyama T \& Machinami R 1993 Overexpression of p53 as a possible prognostic factor in human thyroid carcinoma. American Journal of Surgical Pathology 17 375-381.

Dominguez G, Garcia JM, Pena C, Silva J, Garcia V, Martinez L, Maximiano C, Gomez ME, Rivera JA, Garcia-Andrade C et al. 2006 DeltaTAp73 upregulation correlates with poor prognosis in human tumors: putative in vivo network involving p73 isoforms, p53, and E2F-1. Journal of Clinical Oncology 24 805-815. 
Fagin JA, Matsuo K, Karmakar A, Chen DL, Tang SH \& Koeffler HP 1993 High prevalence of mutations of the $p 53$ gene in poorly differentiated human thyroid carcinomas. Journal of Clinical Investigation 91 179-184.

Fagin JA, Tang SH, Zeki K, Di Lauro R, Fusco A \& Gonsky R 1996 Reexpression of thyroid peroxidase in a derivative of an undifferentiated thyroid carcinoma cell line by introduction of wild-type p53. Cancer Research 56 765-771.

Fedele M, Battista S, Kenyon L, Baldassarre G, Fidanza V, Klein-Szanto AJ, Parlow AF, Visone R, Pierantoni GM, Outwater E et al. 2002 Overexpression of the HMGA2 gene in transgenic mice leads to the onset of pituitary adenomas. Oncogene 21 3190-3198.

Fedele M, Pentimalli F, Baldassarre G, Battista S, KleinSzanto AJ, Kenyon L, Visone R, De Martino I, Ciarmiello A, Arra C et al. 2005 Transgenic mice overexpressing the wild-type form of the HMGA1 gene develop mixed growth hormone/prolactin cell pituitary adenomas and natural killer cell lymphomas. Oncogene 24 3427-3435.

Ferru A, Denis S, Guilhot J, Gibelin H, Tourani JM, Kraimps JL, Larsen CJ \& Karayan-Tapon L 2006 Expression of TAp73 and DeltaNp73 isoform transcripts in thyroid tumours. European Journal of Surgical Oncology 32 228-230.

Flores ER, Sengupta S, Miller JB, Newman JJ, Bronson R, Crowley D, Yang A, McKeon F \& Jacks T 2005 Tumor predisposition in mice mutant for p63 and p73: Evidence for broader tumor suppressor functions for the $\mathrm{p} 53$ family. Cancer Cell 7 363-373.

Fomenkov A, Huang YP, Topaloglu O, Brechman A, Osada M, Fomenkova T, Yuriditsky E, Trink B, Sidransky D \& Ratovitski E 2003 P63 alpha mutations lead to aberrant splicing of keratinocyte growth factor receptor in the HayWells syndrome. Journal of Biological Chemistry 278 23906-23914.

Frasca F, Vella V, Aloisi A, Mandarino A, Mazzon E, Vigneri R \& Vigneri P 2003 p73 tumor-suppressor activity is impaired in human thyroid cancer. Cancer Research 63 5829-5837.

Frasca F, Rustighi A, Malaguarnera R, Altamura S, Vigneri P, Del Sal G, Giancotti V, Pezzino V, Vigneri R \& Manfioletti G 2006 HMGA1 inhibits the function of p53 family members in thyroid cancer cells. Cancer Research 66 2980-2989.

Freebern WJ, Smith JL, Chaudhry SS, Haggerty CM \& Gardner K 2003 Novel cell-specific and dominant negative anti-apoptotic roles of p73 in transformed leukemia cells. Journal of Biological Chemistry 278 2249-2255.

Gaiddon C, Lokshin M, Ahn J, Zhang T \& Prives C 2001 A subset of tumor-derived mutant forms of p53 downregulate p63 and p73 through a direct interaction with the p53 core domain. Molecular and Cellular Biology 21 1874-1887.
Gamble SC, Cook MC, Riches AC, Herceg Z, Bryant PE \& Arrand JE 1999 p53 mutations in tumors derived from irradiated human thyroid epithelial cells. Mutation Research 425 231-238.

Garcia-Rostan G, Costa AM, Pereira-Castro I, Salvatore G, Hernandez R, Hermsem MJ, Herrero A, Fusco A, Cameselle-Teijeiro J \& Santoro M 2005 Mutation of the $P I K 3 C A$ gene in anaplastic thyroid cancer. Cancer Research 65 10199-10207.

Gerasimov G, Bronstein M, Troshina K, Alexandrova G, Dedov I, Jennings T, Kallakury BV, Izquierdo R, Boguniewicz A, Figge H et al. 1995 Nuclear p53 immunoreactivity in papillary thyroid cancers is associated with two established indicators of poor prognosis. Experimental and Molecular Pathology 62 52-62.

Ghioni P, Bolognese F, Duijf PH, Van Bokhoven H, Mantovani R \& Guerrini L 2002 Complex transcriptional effects of p63 isoforms: identification of novel activation and repression domains. Molecular and Cellular Biology 22 8659-8668.

Godballe C, Asschenfeldt P, Jorgensen KE, Bastholt L, Clausen PP, Hansen TP, Hansen O \& Bentzen SM 1998 Prognostic factors in papillary and follicular thyroid carcinomas: p53 expression is a significant indicator of prognosis. Laryngoscope 108 243-249.

Gong JG, Costanzo A, Yang HQ, Melino G, Kaelin WG, Jr, Levrero M \& Wang JY 1999 The tyrosine kinase c-Abl regulates p73 in apoptotic response to cisplatin-induced DNA damage. Nature 399 806-809.

Guan M \& Chen Y 2005 Aberrant expression of DeltaNp73 in benign and malignant tumours of the prostate: correlation with Gleason score. Journal of Clinical Pathology 58 1175-1179.

Harvey M, Vogel H, Lee EY, Bradley A \& Donehower LA 1995 Mice deficient in both $\mathrm{p} 53$ and $\mathrm{Rb}$ develop tumors primarily of endocrine origin. Cancer Research 55 1146-1151.

Hassan I, Wunderlich A, Burchert A, Hoffmann S \& Zielke A 2006 Antisense p53 oligonucleotides inhibit proliferation and induce chemosensitivity in follicular thyroid cancer cells. Anticancer Research 26 1171-1176.

Hibi K, Trink B, Patturajan M, Westra WH, Caballero OL, Hill DE, Ratovitski EA, Jen J \& Sidransky D 2000 AIS is an oncogene amplified in squamous cell carcinoma. PNAS 97 5462-5467.

Hirning-Folz U, Wilda M, Rippe V, Bullerdiek J \& Hameister H 1998 The expression pattern of the Hmgic gene during development. Genes, Chromosomes \& Cancer 23 350-357.

Horie S, Maeta H, Endo K, Ueta T, Takashima K \& Terada T 2001 Overexpression of $\mathrm{p} 53$ protein and MDM2 in papillary carcinomas of the thyroid: correlations with clinicopathologic features. Pathology International 51 11-15.

Hosal SA, Apel RL, Freeman JL, Azadian A, Rosen IB, LiVolsi VA \& Asa SL 1997 Immunohistochemistry localization of p53 in human thyroid neoplasms: correlation with biological behavior. Endocrine Pathology 8 21-28. 
Hunt J 2005 Understanding the genotype of follicular thyroid tumors. Endocrine Pathology 16 311-321.

Hunt JL, LiVolsi VA \& Barnes EL 2004 p63 expression in sclerosing mucoepidermoid carcinomas with eosinophilia arising in the thyroid. Modern Pathology 17 526-529.

Ikawa S, Nakagawara A \& Ikawa Y 1999 P53 family genes: structural comparison, expression and mutation. Cell Death and Differentiation 6 1154-1161.

Imanishi R, Ohtsuru A, Iwamatsu M, Iioka T, Namba H, Seto S, Yano K \& Yamashita S 2002 A histone deacetylase inhibitor enhances killing of undifferentiated thyroid carcinoma cells by p53 gene therapy. Journal of Clinical Endocrinology and Metabolism 87 4821-4824.

Ito Y, Yoshida H, Tomoda C, Uruno T, Miya A, Kobayashi K, Matsuzuka F, Kakudo K, Kuma K \& Miyauchi A 2004 S100A4 expression is an early event of papillary carcinoma of the thyroid. Oncology 67 397-402.

Ito Y, Uramoto H, Funa K, Yoshida H, Jikuzono T, Asahi S, Higashiyama T, Tomoda C, Takamura Y, Miya A et al. 2006 Delta Np73 expression in thyroid neoplasms originating from follicular cells. Pathology 38 205-209.

Jennings T, Bratslavsky G, Gerasimov G, Troshina K, Bronstein M, Dedov I, Alexandrova G \& Figge J 1995 Nuclear accumulation of MDM2 protein in well-differentiated papillary thyroid carcinomas. Experimental and Molecular Pathology 62 199-206.

Klemm JD, Schreiber SL \& Crabtree GR 1998 Dimerization as a regulatory mechanism in signal transduction. Annual Review of Immunology 16 569-592.

Koike M, Fujita F, Komori K, Katoh F, Sugimoto T, Sakamoto Y, Matsuda M \& Fujita M 2004 Dependence of chemotherapy response on p53 mutation status in a panel of human cancer lines maintained in nude mice. Cancer Science 95 541-546.

Koster MI, Lu SL, White LD, Wang XJ \& Roop DR 2006 Reactivation of developmentally expressed p63 isoforms predisposes to tumor development and progression. Cancer Research 66 3981-3986.

Kroll TG 2004 Molecular events in follicular thyroid tumors. Cancer Treatment and Research 122 85-105.

Lohrum MA \& Vousden KH 2000 Regulation and function of the p53-related proteins: same family different rules. Trends in Cell Biology 10 197-202.

Lubitz CC, Gallagher LA, Finley DJ, Zhu B \& Fahey TJ, III 2005 Molecular analysis of minimally invasive follicular carcinomas by gene profiling. Surgery 138 1042-1048 (discussion 1048-9).

Malaguarnera R, Mandarino A, Mazzon E, Vella V, Gangemi P, Vancheri C, Vigneri P, Aloisi A, Vigneri R \& Frasca F 2005 The p53-homologue p63 may promote thyroid cancer progression. Endocrine-Related Cancer 12 953-971.

Marin MC \& Kaelin WG, Jr 2000 p63 and p73: old members of a new family. Biochimica et Biophysica Acta 1470 M93-M100.

Massion PP, Taflan PM, Jamshedur Rahman SM, Yildiz P, Shyr Y, Edgerton ME, Westfall MD, Roberts JR, Pietenpol
JA, Carbone DP et al. 2003 Significance of p63 amplification and overexpression in lung cancer development and prognosis. Cancer Research 63 7113-7121.

McWhirter JR \& Wang JY 1997 Effect of Bcr sequences on the cellular function of the Bcr-Abl oncoprotein.

Oncogene 15 1625-1634.

McWhirter JR, Galasso DL \& Wang JY 1993 A coiled-coil oligomerization domain of Bcr is essential for the transforming function of $\mathrm{Bcr}-\mathrm{Abl}$ oncoproteins. Molecular and Cellular Biology 13 7587-7595.

Melino G, De Laurenzi V \& Vousden KH 2002 p73: friend or foe in tumorigenesis. Nature Reviews. Cancer 2 605-615.

Miettinen M \& Karkkainen P 1996 Differential reactivity of HBME-1 and CD15 antibodies in benign and malignant thyroid tumours. Preferential reactivity with malignant tumours. Virchows Archiv 429 213-219.

Mills AA 2005 p53: link to the past, bridge to the future. Genes \& Development 19 2091-2099.

Mills AA 2006 p63: Oncogene or tumor suppressor? Current Opinion in Genetics \& Development 16 38-44.

Mills AA, Zheng B, Wang XJ, Vogel H, Roop DR \& Bradley A 1999 p63 is a p53 homologue required for limb and epidermal morphogenesis. Nature 398 708-713.

Moll UM 2003 The role of p63 and p73 in tumor formation and progression: coming of age toward clinical usefulness. Clinical Cancer Research 9 5437-5441.

Moll UM \& Slade N 2004 p63 and p73: roles in development and tumor formation. Molecular Cancer Research 2 371-386.

Moll UM, Erster S \& Zaika A 2001 p53, p63 and p73 - solos, alliances and feuds among family members. Biochimica et Biophysica Acta 1552 47-59.

Moretti F, Farsetti A, Soddu S, Misiti S, Crescenzi M, Filetti S, Andreoli M, Sacchi A \& Pontecorvi A 1997 p53 re-expression inhibits proliferation and restores differentiation of human thyroid anaplastic carcinoma cells. Oncogene 14 729-740.

Muller M, Schilling T, Sayan AE, Kairat A, Lorenz K, Schulze-Bergkamen H, Oren M, Koch A, Tannapfel A, Stremmel W et al. 2005 TAp73/LNp73 influences apoptotic response, chemosensitivity and prognosis in hepatocellular carcinoma. Cell Death and Differentiation 12 1564-1577.

Murray-Zmijewski F, Lane DP \& Bourdon JC 2006 p53/p63/p73 isoforms: an orchestra of isoforms to harmonise cell differentiation and response to stress. Cell Death and Differentiation 13 962-972.

Musholt TJ, Brehm C, Hanack J, von Wasielewski R \& Musholt PB 2006 Identification of differentially expressed genes in papillary thyroid carcinomas with and without rearrangements of the tyrosine kinase receptors RET and/or NTRK11. Journal of Surgical Research 131 15-25.

Nagayama Y, Yokoi H, Takeda K, Hasegawa M, Nishihara E, Namba H, Yamashita S \& Niwa M 2000 Adenovirusmediated tumor suppressor p53 gene therapy for 
anaplastic thyroid carcinoma in vitro and in vivo. Journal of Clinical Endocrinology and Metabolism $\mathbf{8 5}$ 4081-4086.

Nakagawa T, Takahashi M, Ozaki T, Watanabe K, Hayashi S, Hosoda M, Todo S \& Nakagawara A 2003 Negative autoregulation of p73 and p53 by DeltaNp73 in regulating differentiation and survival of human neuroblastoma cells. Cancer Letters 197 105-109.

Narimatsu M, Nagayama Y, Akino K, Yasuda M, Yamamoto T, Yang TT, Ohtsuru A, Namba H, Yamashita S, Ayabe Het al. 1998 Therapeutic usefulness of wild-type p53 gene introduction in a p53-null anaplastic thyroid carcinoma cell line. Journal of Clinical Endocrinology and Metabolism $\mathbf{8 3}$ 3668-3672.

Nikiforov YE, Nikiforova MN, Gnepp DR \& Fagin JA 1996 Prevalence of mutations of RAS and P53 in Benign and Malignant thyroid tumors from children exposed to radiation after the chernobyl nuclear accident. Oncogene 13 687-693.

Nishida T, Nakao K, Hamaji M, Nakahara MA \& Tsujimoto M 1996 Overexpression of p53 protein and DNA content are important biologic prognostic factors for thyroid cancer. Surgery 119 568-575.

Olivier M, Eeles R, Hollstein M, Khan MA, Harris CC \& Hainaut P 2002 The IARC TP53 database: new online mutation analysis and recommendations to users. Human Mutation 19 607-614.

Orlandi F, Saggiorato E, Pivano G, Puligheddu B, Termine A, Cappia S, De Giuli P \& Angeli A 1998 Galectin-3 is a presurgical marker of human thyroid carcinoma. Cancer Research 58 3015-3020.

Park KY, Koh JM, Kim YI, Park HJ, Gong G, Hong SJ \& Ahn IM 1998 Prevalences of Gs alpha, ras, p53 mutations and ret/PTC rearrangement in differentiated thyroid tumours in a Korean population. Clinical Endocrinology 49 317-323.

Park BJ, Lee SJ, Kim JI, Lee CH, Chang SG, Park JH \& Chi SG 2000 Frequent alteration of p63 expression in primary bladder carcinomas. Cancer Research 60 3370-3374.

Pisarchik AV, Ermak G, Kartel NA \& Figge J 2000 Molecular alterations involving p53 codons 167 and 183 in papillary thyroid carcinomas from chernobylcontaminated regions of belarus. Thyroid 10 25-30.

Pollina L, Pacini F, Fontanini G, Vignati S, Bevilacqua G \& Basolo F 1996 bcl-2, p53 and proliferating cell nuclear antigen expression is related to the degree of differentiation in thyroid carcinomas. British Journal of Cancer 73 139-143.

Portella G, Scala S, Vitagliano D, Vecchio G \& Fusco A 2002 ONYX-015, an E1B gene-defective adenovirus, induces cell death in human anaplastic thyroid carcinoma cell lines. Journal of Clinical Endocrinology and Metabolism. 87 2525-2531.

Portella G, Pacelli R, Libertini S, Cella L, Vecchio G, Salvatore M \& Fusco A 2003 ONYX-015 enhances radiation-induced death of human anaplastic thyroid carcinoma cells. Journal of Clinical Endocrinology and Metabolism 88 5027-5032.

Pozniak CD, Radinovic S, Yang A, McKeon F, Kaplan DR \& Miller FD 2000 An anti-apoptotic role for the p53 family member, p73, during developmental neuron death. Science 289 304-306.

Preto A, Reis-Filho JS, Ricardo S \& Soares P 2002 P63 expression in papillary and anaplastic carcinomas of the thyroid gland: lack of an oncogenetic role in tumorigenesis and progression. Pathology, Research and Practice 198 449-454.

Quiros RM, Ding HG, Gattuso P, Prinz RA \& Xu X 2005 Evidence that one subset of anaplastic thyroid carcinomas are derived from papillary carcinomas due to BRAF and p53 mutations. Cancer 103 2261-2268.

Reeves R 2001 Molecular biology of HMGA proteins: hubs of nuclear function. Gene 277 63-81.

Reis-Filho JS \& Schmitt FC 2002 Taking advantage of basic research: p63 is a reliable myoepithelial and stem cell marker. Advances in Anatomic Pathology 9 280-289.

Reis-Filho JS, Preto A, Soares P, Ricardo S, CameselleTeijeiro J \& Sobrinho-Simoes M 2003 p63 expression in solid cell nests of the thyroid: further evidence for a stem cell origin. Modern Pathology 16 43-48.

Rohaly G, Chemnitz J, Dehde S, Nunez AM, Heukeshoven J, Deppert W \& Dornreiter I 2005 A novel human p53 isoform is an essential element of the ATR-intra-S phase checkpoint. Cell 122 21-32.

Ruter A, Dreifus J, Jones M, Nishiyama R \& Lennquist S 1996 Overexpression of p53 in tall cell variants of papillary thyroid carcinoma. Surgery 120 1046-1050.

Salvatore D, Celetti A, Fabien N, Paulin C, Martelli ML, Battaglia C, Califano D, Monaco C, Viglietto G, Santoro M et al. 1996 Low frequency of p53 mutations in human thyroid tumours; p53 and Ras mutation in two out of fiftysix thyroid tumours. European Journal of Endocrinology 134 177-183.

Sasaki Y, Morimoto I, Ishida S, Yamashita T, Imai K \& Tokino T 2001 Adenovirus-mediated transfer of the p53 family genes, p73 and p51/p63 induces cell cycle arrest and apoptosis in colorectal cancer cell lines: potential application to gene therapy of colorectal cancer. Gene Therapy 8 1401-1408.

Save V, Nylander K \& Hall PA 1998 Why is p53 protein stabilized in neoplasia? Some answers but many more questions? Journal of Pathology 184 348-350.

Scala S, Portella G, Fedele M, Chiappetta G \& Fusco A 2000 Adenovirus-mediated suppression of $\mathrm{HMGI}(\mathrm{Y})$ protein synthesis as potential therapy of human malignant neoplasias. PNAS 97 4256-4261.

Schelfhout LJ, Van Muijen GN \& Fleuren GJ 1989 Expression of keratin 19 distinguishes papillary thyroid carcinoma from follicular carcinomas and follicular thyroid adenoma. American Journal of Clinical Pathology 92 654-658. 
Serber Z, Lai HC, Yang A, Ou HD, Sigal MS, Kelly AE, Darimont BD, Duijf PH, Van Bokhoven H, McKeon F et al. 2002 A C-terminal inhibitory domain controls the activity of $\mathrm{p} 63$ by an intramolecular mechanism. Molecular and Cellular Biology 22 8601-8611.

Sgarra R, Rustighi A, Tessari MA, Di Bernardo J, Altamura S, Fusco A, Manfioletti G \& Giancotti V 2004 Nuclear phosphoproteins HMGA and their relationship with chromatin structure and cancer. FEBS Letters 574 1-8.

Shahedian B, Shi Y, Zou M \& Farid NR 2001 Thyroid carcinoma is characterized by genomic instability: evidence from p53 mutations. Molecular Genetics and Metabolism 72 155-163.

Smida J, Zitzelsberger H, Kellerer AM, Lehmann L, Minkus G, Negele T, Spelsberg F, Hieber L, Demidchik EP, Lengfelder E et al. 1997 p53 mutations in childhood thyroid tumours from Belarus and in thyroid tumours without radiation history. International Journal of Cancer 73 802-807.

Smith KM \& Van Etten RA 2001 Activation of c-Abl kinase activity and transformation by a chemical inducer of dimerization. Journal of Biological Chemistry 276 24372-24379.

Soares P, Cameselle-Teijeiro J \& Sobrinho-Simoes M 1994 Immunohistochemical detection of p53 in differentiated, poorly differentiated and undifferentiated carcinomas of the thyroid. Histopathology 24 205-210.

Stewart SA \& Weinberg RA 2006 Telomeres: cancer to human aging. Annual Review of Cell and Developmental Biology 22 531-557.

Strano S, Munarriz E, Rossi M, Castagnoli L, Shaul Y, Sacchi A, Oren M, Sudol M, Cesareni G \& Blandino G 2001 Physical interaction with Yes-associated protein enhances p73 transcriptional activity. Journal of Biological Chemistry 276 15164-15173.

Suchy B, Waldmann V, Klugbauer S \& Rabes HM 1998 Absence of RAS and p53 mutations in thyroid carcinomas of children after Chernobyl in contrast to adult thyroid tumours. British Journal of Cancer 77 952-955.

Tanner S \& Barberis A 2004 CP-31398, a putative p53stabilizing molecule tested in mammalian cells and in yeast for its effects on p53 transcriptional activity. Journal of Negative Results in Biomedicine 35.

Thanos CD \& Bowie JU 1999 p53 Family members p63 and p73 are SAM domain-containing proteins. Protein Science 8 1708-1710.

Treff NR, Dement GA, Adair JE, Britt RL, Nie R, Shima JE, Taylor WE \& Reeves R 2004a Human KIT ligand promoter is positively regulated by HMGA1 in breast and ovarian cancer cells. Oncogene 23 8557-8562.

Treff NR, Pouchnik D, Dement GA, Britt RL \& Reeves R $2004 b$ High-mobility group A1a protein regulates Ras/ERK signaling in MCF-7 human breast cancer cells. Oncogene 23 777-785.
Ugur H, Sayan AE, Ozdamar SO, Kanpolat Y \& Ozturk M 2004 Expression of TAP73 and DeltaNP73 in malignant gliomas. Oncology Reports 11 1337-1341.

Unger P, Ewart M, Wang BY, Gan L, Kohtz DS \& Burstein DE 2003 Expression of p63 in papillary thyroid carcinoma and in Hashimoto's thyroiditis: a pathobiologic link? Human Pathology 34 764-769.

Vella V, Zhu J, Frasca F, Li CY, Vigneri P, Vigneri R \& Wang JY 2003 Exclusion of c-Abl from the nucleus restrains the p73 tumor suppression function. Journal of Biological Chemistry 278 25151-25157.

Vikhanskaya F, D’Incalci M \& Broggini M 2000 p73 competes with p53 and attenuates its response in a human ovarian cancer cell line. Nucleic Acids Research 28 513-519.

Vikhanskaya F, Marchini S, Marabese M, Galliera E \& Broggini M 2001 p73a overexpression is associated with resistance to treatment with DNA-damaging agents in a human ovarian cancer cell line. Cancer Research 61 935-938.

Westfall MD \& Pietenpol JA 2004 p63: molecular complexity in development and cancer. Carcinogenesis 25 857-864.

Wood LJ, Maher JF, Bunton TE \& Resar LM 2000a The oncogenic properties of the HMGI gene family. Cancer Research 60 4256-4261.

Wood LJ, Mukherjee M, Dolde CE, Xu Y, Maher JF, Bunton TE, Williams JB \& Resar LM $2000 b$ HMG-I/Y, a new c-Myc target gene and potential oncogene. Molecular and Cellular Biology 20 5490-5502.

Wyllie FS, Haughton MF, Blaydes JP, Schlumberger M \& Wynford-Thomas D 1995 Evasion of p53-mediated growth control occurs by three alternative mechanisms in transformed thyroid epithelial cells. Oncogene $\mathbf{1 0}$ 49-59.

Xu Y, Sumter TF, Bhattacharya R, Tesfaye A, Fuchs EJ, Wood LJ, Huso DL \& Resar LM 2004 The HMG-I oncogene causes highly penetrant, aggressive lymphoid malignancy in transgenic mice and is overexpressed in human leukemia. Cancer Research 64 3371-3375.

Yamaguchi K, Wu L, Caballero OL, Hibi K, Trink B, Resto V, Cairns P, Okami K, Koch WM, Sidransky D et al. 2000 Frequent gain of the p40/p51/p63 gene locus in primary head and neck squamous cell carcinoma. International Journal of Cancer 86 684-689.

Yang A, Kaghad M, Wang Y, Gillett E, Fleming MD, Dotsch V, Andrews NC, Caput D \& McKeon F 1998 p63, a p53 homolog at 3q27-29, encodes multiple products with transactivating, death-inducing, and dominant-negative activities. Molecular Cell 2 305-316.

Yang A, Walker N, Bronson R, Kaghad M, Oosterwegel M, Bonnin J, Vagner C, Bonnet H, Dikkes P, Sharpe A et al. 2000 p73-deficient mice have neurological, pheromonal and inflammatory defects but lack spontaneous tumours. Nature 404 99-103. 
Zaika AI, Slade N, Erster SH, Sansome C, Joseph TW, Pearl M, Chalas E \& Moll UM 2002 DeltaNp73, a dominantnegative inhibitor of wild-type p53 and TAp73, is up-regulated in human tumors. Journal of Experimental Medicine 196 765-780.

Zedenius J, Larsson C, Wallin G, Backdahl M, Aspenblad U, Hoog A, Borresen AL \& Auer G 1996 Alterations of p53 and expression of WAF1/p21 in human thyroid tumors. Thyroid 6 1-9.

Zeimet AG \& Marth C 2003 Why did p53 gene therapy fail in ovarian cancer? Lancet Oncology 4 415-422.
Zhou X, Benson KF, Ashar HR \& Chada K 1995 Mutation responsible for the mouse pygmy phenotype in the developmentally regulated factor HMGI-C. Nature 376 771-774.

Zhu J, Jiang J, Zhou W \& Chen X 1998 The potential tumor suppressor p73 differentially regulates cellular p53 target genes. Cancer Research 58 5061-5065.

Zou M, Shi Y, al-Sedairy S, Hussain SS \& Farid NR 1995 The expression of the MDM2 gene, a p53 binding protein, in thyroid carcinogenesis. Cancer 76 314-318. 